\title{
Analysis of Product Variation and Service Quality on Repurchase Intention Mediated by Customer Satisfaction
}

\author{
Afika Putri Anjani \\ TB Triguna \\ afikaanjani94@gmail.com \\ https://doi.org/10.37715/rmbe.v1i2.2435
}

\begin{abstract}
The purpose of this study was to determine customer satisfaction as a mediating variable through product variations and service quality to repurchase intention. This research uses a quantitative method with 92 respondents of TB Triguna customers, this research uses a simple random sampling technique. Data collection techniques are using a questionnaire and data analysis used is using SmartPLS (SEM). The analysis technique used is the path analysis test with the aim to find out how much influence customer satisfaction as a mediating variable through product variation and service quality variables on repurchase intention. The results showed that product variation and service quality significantly influenced repurchase intention mediated by customer satisfaction. With each p-value $<0.05$ so that the five hypotheses are accepted and indicate that the variable repurchase intention and customer satisfaction can be explained by variable variations in product and overall service quality by $89.7 \%$ and the rest is influenced by other factors outside the research model this is $\mathbf{1 0 . 3 \%}$.
\end{abstract}

Keywords - Product Variation, Service Quality, Customer Satisfaction, Repurchase Intention.

\section{Introduction}

In the face of changes in the current era of globalization, Indonesia is experiencing a fairly rapid development in all fields, one of which is the business sector. This is indicated by data submitted by the Central Statistics Agency that the number of entrepreneurs increased by 3.10 percent in 2018. In the previous year it was 1.67 percent of the 225 million population. This figure shows that more and more entrepreneurs or new businesses are entering the market by implementing various strategies to attract as many consumers as possible. The goal of the business owner is not only to get as many consumers as possible but also to retain the customers that have been obtained so far.

The building shop (TB) Triguna is a business entity that provides building materials, this shop sells building equipment and supplies. This business was first established by Mrs. Sunarsih in 2015 which is located on Jalan Karangrejo Purwosari Pasuruan. Product variations and customer satisfaction are also inseparable from the role of improving the quality of services provided by TB Triguna to customers. Service quality is the level of excellence that is expected to meet consumer desires for a product related to services provided that meet or exceed consumer expectations (Kotler \& Keller, 2016, pp. 153-158). The higher the role of service quality (Tangible, Reliability, Responsiveness, Assurance, and Empathy) the higher the satisfaction, through improving service quality (Duarte et al., 2016). Customer satisfaction can be interpreted as a level where the needs, desires, and expectations of customers can be met which will result in repeat purchases or continued loyalty (Aji \& Marleni, 2018). Repurchase intention can be interpreted as a form of individual judgment to repurchase after receiving good service quality and getting a match between their wants and needs in the same company (Fang et al., 2016).

\section{Literature Review}

\subsection{Previous Research}

Repurchase intention can be interpreted as a form of individual assessment to repurchase after getting good service quality and getting a match between their wants and needs in the same company (Fang et al., 2016). Other studies also show that the impact of the application of self-service technology (SST) systems. The facts show that today's technological advances change the facet of the interaction between a company and its customers, resulting in an increase in service standards. High service quality will lead to higher satisfaction (Shahid Iqbal et al., 2018). 
Another study entitled repurchase intention: the effect of service quality, system quality, information quality, and customer satisfaction as mediating role: a PLS approach of m-commerce ride-hailing service in Vietnam. The results of this study indicate that the quality of electronic services, customer satisfaction on the intention to repurchase have a significant positive effect. The variables in this study are service quality, system quality, information quality, overall (Septiawati, 2018) perceived service quality, customer satisfaction, and online repurchase intention. In addition, to improve service quality, companies should consider improving the adequacy and usability of the application. Such an application contains information that can be updated regularly and of course be more specific (Ngoc Duy Phuong \& Thi Dai g, 2018).

The results of other studies indicate that the perception of service quality has an effect on consumer satisfaction. Consumer satisfaction affects repurchase intention, while the choice of brand acting as a partial mediator has an effect on customer satisfaction with repurchase intention. The variables used in this study are service quality perception, customer satisfaction, and repurchase intention (Nugroho et al., 2017).

\subsection{Theoretical basis}

\subsubsection{Product Variations}

Kotler (2013, p. 15) argues that product variety can be interpreted as a collection of products offered by a company to consumers. If the company is able to provide goods that are diverse in terms of color, size, price, appearance, and product availability, it will make it easier for the company to get consumers. Because with the increasing number of choices available, consumers will find it easier to choose products according to their wishes (Kotler, 2008, p. 234). Product variation indicators can be in the form of size variations, product quality, product completeness, and brand variations according to Utami (2006, p. 116):

1. Size Variations

2. Product Quality Variations

3. Product completeness variations

4. Brand Variations

\subsubsection{Service quality}

Quality can be interpreted as suitability for use, which can be interpreted as one of the important components that a customer or buyer will use in considering buying a product (Kotler \& Keller, 2016). Service quality is considered good when it is able to exceed what is expected by the customer. On the other hand, service quality is said to be bad if it is below what customers expect (Faradisa et al., 2016). Five dimensions of service quality that researchers can use in assessing and measuring according to Zeithaml and Bitner (Faradisa et al., 2016):

1. Tangibles (direct evidence),

2. Reliability (reliable),

3. Responsiveness (responsiveness)

4. Assurance (guarantee),

5. Empathy (empathy).

\subsubsection{Customer satisfaction}

Customer satisfaction is defined as the level of one's feelings after comparing the performance (or results) that he feels compared to his expectations (Kotler \& Keller, 2016). Satisfied customers have the potential to become loyal customers and are able to attract other customers. And it can also be used as a key to increasing company profitability (Wikhamn, 2019). Customer satisfaction is a measure of a company's performance related to a series of customer requirements (Hill \& Alexander, 2017) The following are indicators that can be used to measure customer satisfaction according to Arsyanti dan Astuti (2016), including:

1. Feeling satisfied with the performance provided by the company

2. Fulfillment of customer expectations after making a purchase transaction of a product

3. There are no complaints about the consumption of the products purchased

4. Satisfied with the benefits of the product that has been purchased

5. Satisfied with product quality

2.2.4. Repurchase Intention

According to Hellier, et al. (Hellier et al., 2003) repurchase intention is a person's planned decision to repurchase certain products and services, taking into account the experience situation that occurs after shopping through positive or negative responses. The repurchase decision occurs due to factors that influence the customer's repurchase interest such as feeling the benefits felt after making a purchase, trust, comfort during the buying process (Ebrahim et al., 2016). The desire to make repeat purchases allows increasing the number of purchases, thus creating 
a great commitment to customers to return to using the product (Faradisa et al., 2016). According to Hellier, et al. (2003) suggests that there are four indicators to measure repurchase requests, namely transactional interest, exploratory interest referential interest, and preferential interest.

\section{Research Methods}

\subsection{Analysis Model}

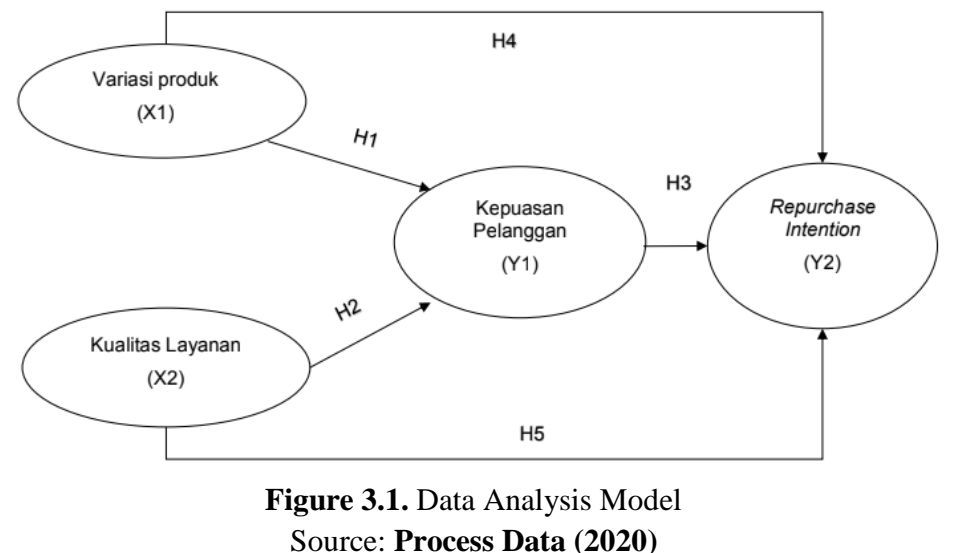

\subsection{Hypothesis}

Source: Process Data (2020)

1. H1: Product variations have a significant effect on TB Triguna customer satisfaction.

2. H2: Service quality has a significant effect on customer satisfaction for TB Triguna.

3. H3 : Customer satisfaction has a significant effect on repurchase intention for TB Triguna.

4. H4: Product variations have a significant effect on repurchase intention mediated by TB Triguna customer satisfaction.

5. H5: Service quality has a significant effect on repurchase intention mediated by TB Triguna customer satisfaction.

\subsection{Research Approach}

The approach used in this research is a quantitative research approach. This study uses a survey method, namely a structured questionnaire given to respondents and designed to obtain specific information (Malhotra, 2010). The design used in this study is a conclusive research design, this research design aims to test hypotheses related to various variables. This study aims to examine the causality of exogenous variables, namely the influencing variables, namely product variation (X1) and service quality (X2). As for the endogenous variables, namely the variables that are affected, in this study, namely customer satisfaction (Y1) as a mediator variable and repurchase intention (Y2). This study uses data analysis techniques Partial Least Square (PLS), which is used to analyze the Structure Equation Modeling (SEM) assisted by the SmartPLS 3.0 M3 program.

The research will be conducted at the Triguna Building Store on Jalan Karangrejo, Purwosari, Pasuruan. This is because, this study examines the family business, namely TB Triguna. And all subjects related to the study were up to November 2019, while sampling was carried out in April 2019. The population used in this study were all TB Triguna customers, totaling 1,092 in April. In this study using simple random sampling, this sampling technique can be interpreted as taking sample members from a population that is carried out randomly without regard to the strata that exist in the population (Sugiyono, 2017).

A sampling of respondents in this study used the formula proposed by Slovin as follows with the percentage of error that was tolerated in sampling, in this study using e: $10 \%(0.1)$ and a confidence level of $90 \%$ :

Description:

$$
n=\frac{N}{1+N \cdot e^{2}}
$$

$\mathrm{n}=$ sample size

$\mathrm{N}=$ population size

$\mathrm{e}=($ error tolerance) the error rate in selecting sample members is tolerated by $10 \%$ 
Based on the results of the sample count using the Slovin formula, the respondents in this study were 91.61 and then rounded up to 92 respondents. The random sampling technique used in this study by the researcher is by taking a simple sample by using Systematic Sampling, this technique measures the population to make the sample "how many" with certain intervals.

The types and sources of data used in this study are primary data collected directly by conducting research in TB Triguna by distributing questionnaires to customers who have made purchases at least twice to TB Triguna, and secondary data obtained through documents, journal books and others. . The questionnaire in this study used a Likert scale for measurement. Each question answer is scored with the provisions, for strongly agree answers are given a score of 5, agreed answers are given a score of 4, Neutral answers are given a score of 3, disagreed answers are given a score of 2, and finally, strongly disagree answers are given a score of 1 .

\subsection{Data Analysis Technique}

\subsubsection{Descriptive analysis}

Data analysis, in this case, was carried out using statistics. This data analysis is intended for grouping data based on the variables studied, tabulating data based on variables obtained from all respondents.

\subsubsection{Inferential analysis}

Inferential statistical data analysis was measured using SmartPLS 3.0 software starting from testing the measurement model (outer model), testing the model structure (inner model), and testing hypotheses (Ghozali \& Latan, 2015). Based on the hypothesis in this study, the data analysis method used is SEM (Structural Equation Modeling) analysis with the PLS (Partial Least Square) approach. The data analysis technique with the PLS technique was carried out through three stages, namely:

1. The first stage is to test the measurement outer model, which is to test the validity and construct reliability of each indicator. To measure the level of reliability of a study variable refers to the value of Cronbach's alpha and composite reliability.

Table 3.1. Rule of thumb validity of reflective outer model

\begin{tabular}{|c|c|c|}
\hline Validity & Parameter & Rule of Thumb \\
\hline \multirow{2}{*}{ Convergent Validity } & Loading factor & $>0,5$ \\
\cline { 2 - 3 } & AVE & $>0,5$ \\
\hline \multirow{2}{*}{ Discriminant validity } & Cross loading & $>0,7$ \\
\cline { 2 - 3 } & Fornell-larcker & \\
\hline \multirow{2}{*}{ Reliability } & Cronbach's Alpha & $>0,7$ \\
\cline { 2 - 3 } & Composite reliability & $>0,7$ \\
\hline
\end{tabular}

Source: PLS Technical concept, and application of SmartPLS 3.0 (Ghozali \& Latan, 2015)

2. The second stage is to conduct a structural inner model test which aims to determine whether there is an influence between variables/correlation between the constructs measured by using the t-test of the PLS itself. This stage can be measured by looking at the value of the R-Square Model (coefficient of determination) which shows how much influence between variables. The next step is the estimation of the path coefficient which is the estimated value for the path relationship in the structural model obtained through the bootstrapping procedure (Path coefficient) with a significant value if the statistical $t$ value is greater than 1.96 (significance level 5\%) or can be said to be greater than 1.65 (significance lever 10\%) on each line linkage. Moreover, by looking at the value of $\mathrm{f} 2 \mathrm{can}$ be interpreted if a variable has influenced Lemar, medium or large at a structural level. Rated M 2 of 0.02 can be considered to have a weak influence latent predictor variable, and the value of 0.15 can be considered to have considerable influence and the value of 0.35 can be considered to have a strong influence on the latent predictor variables.

3. The final stage is related to hypothesis testing using the bootstrapping method to produce $\mathrm{t}$-statistical values to test the outer loading and path analysis. Each relationship path is used to test the hypothesis. The $t$-statistic value will be compared with the result of the t-table value. Research that uses a $95 \%$ confidence level so that the level of precision or limit of inaccuracy $(\alpha)=5 \%=0.05$, the $t$-table value is 1.65 . If the value of $\mathrm{t}$-statistics is less than the value of $\mathrm{t}$-table ( $\mathrm{t}$-statistics < 1.65), then $\mathrm{H} 0$ is accepted and $\mathrm{Ha}$ is rejected and if the value of t-statistics is greater than the value of t-table (t-statistics $>1.65$ ) then Ho is rejected and $\mathrm{Ha}$ is accepted. In addition to paying attention to the t-table value to test the hypothesis that 
it is accepted or rejected, it can be seen through the p-value with the criteria that the p-value is smaller than 0.05 , then Ha is accepted and if it is greater than 0.05 then Ho is rejected.

\subsubsection{Model PLS}

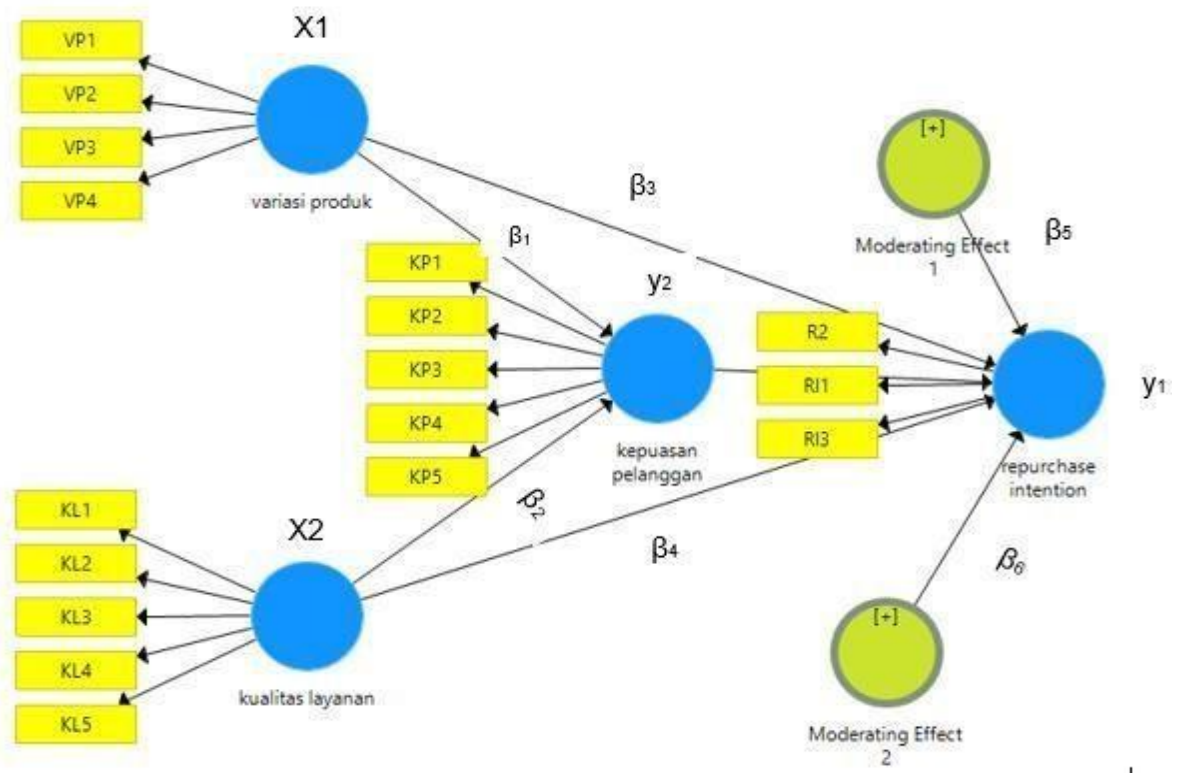

\subsubsection{PLS Equation}

Figure 3.1. PLS models $S$

For endogenous (reflective) latent variables:

$$
\begin{gathered}
y_{1}=\beta_{1} X_{1}+\beta_{2} X_{2}+\varepsilon_{2} \\
y_{2}=\beta_{3} X_{1}+\beta_{4} X_{2}+\beta_{5} M_{1}+\beta_{6} M_{2}+\varepsilon_{2}
\end{gathered}
$$

The meaning of the notation used in the equations in the PLS model is:

$\beta=$ Beta, coefficient of influence of endogenous variables on other endogenous variables

$\varepsilon=$ Epilson, states the measurement error associated with endogenous variables

$\mathrm{X}=$ declares manifest variables related to exogenous variables

$\mathrm{Y}=$ declares manifest variables related to endogenous variables

$\mathrm{M}=$ declare moderator variable

\section{Result and Discussion}

\subsection{Descriptive Analysis}

\subsubsection{Respondents Descriptive Analysis}

Respondent data related to gender, education, occupation, and purchase. Based on gender data, with the total number of respondents as many as 92 people, it can be seen that the number of male respondents is more than female respondents. With the percentage of men as much as 65.2 percent while women as much as 34.8 percent. The grouping of respondents based on education level shows that most of the last educated respondents are junior high school with a total of 32 people (34.8 percent), elementary school graduates as many as 30 people (32.6 percent), then high school graduates as many as 16 people (17.4), undergraduate graduates as many as 8 people (8.7 people). percent), diplomas as many as 4 people ( 4.3 percent), postgraduate graduates 1 person (1.1 percent) and others as many as 1.2 percent. The grouping of respondents based on occupation is dominated by private workers as many as 38 people (41.2 percent), entrepreneurs as many as 32 people (34.8 percent), civil servants as many as 9 people ( 9.8 percent), BUMN as many as 6 people ( 6.5 percent), then retirees as many as 6 people ( 6.5 percent) and one student (1.1 percent). Based on the grouping of purchases at TB Triguna, the results showed that the majority of customers who bought 3 times were 35 people with a percentage of 38 percent, and more than 4 times as many as 34 people visited TB Triguna to make purchases, and bought twice as many as 23 respondents with a percentage of 25 percent. 


\subsubsection{Descriptive Analysis of Research Variables}

1. Descriptive analysis of product variation variables

Table 4.1. Product Variations

\begin{tabular}{|l|c|r|r|l|r|}
\hline & $\mathrm{N}$ & Minimum & Maximum & Mean & Std. Deviation \\
\hline VP1 & 92 & 3.00 & 5.00 & 4.0543 & .54196 \\
VP2 & 92 & 2.00 & 5.00 & 4.1739 & .76473 \\
VP3 & 92 & 3.00 & 5.00 & 3.9022 & .55588 \\
VP4 & 92 & 4.00 & 5.00 & 4.2609 & .44152 \\
Valid N & 92 & & & & \\
(listwise) & & & & & \\
\hline
\end{tabular}

Source: data processed through SPSS, 2019

The highest average is VP 4 (brand variation), product variation with brand variation indicator with an average of 4,2609. And the lowest mean value for the indicator is VP3 (product completeness) with a value of 3.9022. Meanwhile, the highest standard deviation is the VP2 (product quality) indicator with a value of 0.76473 , which means that the respondents' answers to the product variation indicator 2 are more heterogeneous. Compared to respondents' answers on other indicators.

2. Descriptive analysis of service quality variables

Table 4.2. Service Quality

\begin{tabular}{|l|r|r|r|r|r|}
\hline & N & Minimum & Maximum & Mean & Std. Deviation \\
\hline KL1 & 92 & 1.00 & 5.00 & 2.9565 & 1.06815 \\
KL2 & 92 & 3.00 & 5.00 & 4.0652 & .67619 \\
KL3 & 92 & 1.00 & 5.00 & 2.9022 & 1.03838 \\
KL4 & 92 & 2.00 & 5.00 & 4.0870 & .58652 \\
KL5 & 92 & 3.00 & 5.00 & 4.0652 & .50935 \\
Valid N & 92 & & & & \\
(listwise) & & & & & \\
\hline
\end{tabular}

Source: data processed through SPSS, 2019

The highest average indicator is the KL4 assurance indicator. This indicator relates to question items such as knowledge of TB Triguna employees related to the products sold, how employees are able to understand what customers need and are appropriate in providing goods. And the lowest average is the KL3 (responsiveness) indicator. While the highest standard deviation value is the KL1 indicator with a value of 1.0685 , it shows that the answers from respondents to this indicator are more heterogeneous than respondents' answers to other indicators.

3. Descriptive analysis of customer satisfaction variables

Table 4.3. Customer satisfaction

\begin{tabular}{|l|r|r|r|r|r|}
\hline & N & Minimum & Maximum & Mean & Std. Deviation \\
\hline KP1 & 92 & 3.00 & 5.00 & 4.0543 & .54196 \\
KP2 & 92 & 2.00 & 5.00 & 4.1739 & .76473 \\
KP3 & 92 & 3.00 & 5.00 & 3.9022 & .55588 \\
KP4 & 92 & 4.00 & 5.00 & 4.2609 & .44152 \\
KP5 & 92 & 2.00 & 5.00 & 4.0652 & .70795 \\
Valid N (listwise) & 92 & & & & \\
\hline \multicolumn{7}{|r|}{ Source. } \\
\hline
\end{tabular}

Source: data processed through SPSS, 2019

Of the five indicators, the highest average value is the indicator of satisfaction with the product that has been purchased (KP4) with a value of 4.26. Question items related to this indicator are the compatibility between the products and services provided to customers and the lowest average is the KP3 indicator (no complaints) with a value of 3.9022. Meanwhile, the highest standard deviation is the KP2 indicator of 0.76473 . This means that respondents' answers to these indicators are more heterogeneous than respondents' answers to other indicators. 
4. Descriptive analysis of repurchase intention variable

Table 4.4. Repurchase Intention

\begin{tabular}{|c|c|c|c|c|c|}
\hline & $\mathrm{N}$ & Minimum & Maximum & Mean & Std. Deviation \\
\hline RI1 & 92 & 2.00 & 5.00 & 4.1739 & .76473 \\
\hline RI2 & 92 & 3.00 & 5.00 & 4.1087 & 68671 \\
\hline RI3 & 92 & 4.00 & 5.00 & 4.2609 & .44152 \\
\hline Valid N (listwise) & 92 & & & & \\
\hline
\end{tabular}

The highest average of the preferential interest indicator items is 4.26 , namely the RI 3 indicator, this is related to the customer's choice in making TB Triguna the first to make a purchase. The highest value for the standard deviation is in the RI1 indicator with a value of 0.76473 which means that the respondents' answers to the repurchase intention 1 indicator are more heterogeneous than the answers to other repurchase intention indicators.

\subsection{SEM-PLS Early Model}

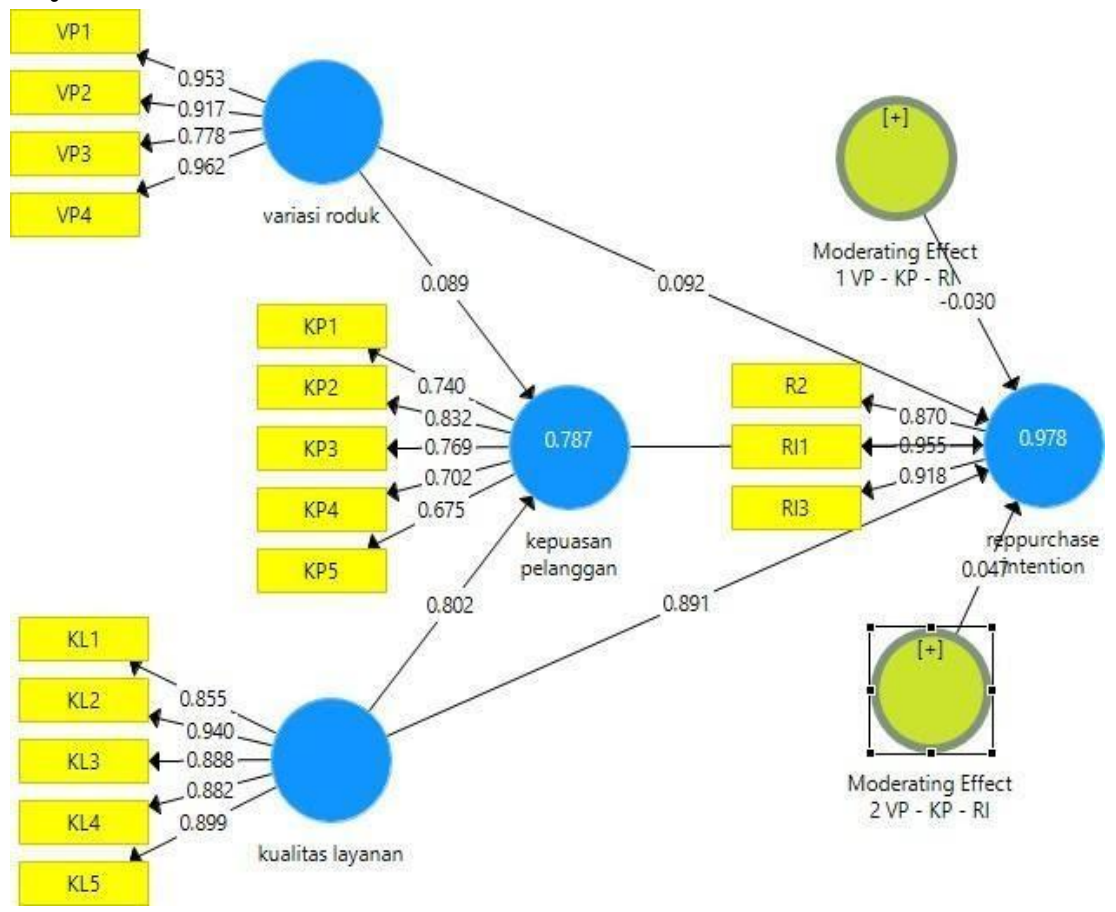

Figure 4.1. PLS Early Model

\subsubsection{Evaluation of Measurement Model (Outer Model)}

1. Convergent Validity

Table 4.5. Outer Loading

\begin{tabular}{|c|c|c|c|}
\hline Variable & Indicator & Outer loading & Conclusion \\
\hline \multirow[t]{4}{*}{ Product Variation $\left(\mathrm{X}_{1}\right)$} & VP.1 & 0,953 & Valid \\
\hline & VP.2 & 0,917 & Valid \\
\hline & VP.3 & 0,778 & Valid \\
\hline & VP.4 & 0,962 & Valid \\
\hline \multirow[t]{5}{*}{ Quality of Service $\left(\mathrm{X}_{2}\right)$} & KL.1 & 0,855 & Valid \\
\hline & KL.2 & 0,940 & Valid \\
\hline & KL.3 & $\mathbf{0 , 8 8 8}$ & Valid \\
\hline & KL.4 & 0,882 & Valid \\
\hline & KL.5 & 0,899 & Valid \\
\hline \multirow[t]{5}{*}{ Customer Satisfaction $\left(\mathrm{Y}_{1}\right)$} & KP.1 & 0,740 & Valid \\
\hline & KP.2 & 0,832 & Valid \\
\hline & KP.3 & 0,769 & Valid \\
\hline & KP.4 & 0,702 & Valid \\
\hline & KP.5 & 0,675 & Valid \\
\hline
\end{tabular}




\begin{tabular}{|l|l|l|l|}
\hline \multirow{3}{*}{ Repurchase Intention (Y) } & RI.1 & $\mathbf{0 , 8 7 0}$ & Valid \\
\cline { 2 - 4 } & RI.2 & $\mathbf{0 , 9 5 5}$ & Valid \\
\cline { 2 - 4 } & RI.3 & $\mathbf{0 , 9 1 8}$ & Valid \\
\hline
\end{tabular}

Source: data processed through SmartPLS

The table above shows that each indicator on the variable has an outer loading value of more than 0.70 . So that all indicators are declared feasible or valid to be used in this study and can be continued by analyzing more deeply. However, there is one indicator item that is worth 0.675 in KP5. This value is still sufficient to meet the convergent validity requirements because it is in the range of values from 0.5 to 0.6 which has been submitted by Chin (1998, as cited in Ghozali \& Latan, 2015). The following is the initial cross loading table:

Table 4.6. Cross Loading

\begin{tabular}{|l|r|r|r|r|}
\hline Indicator & Customer satisfaction & Service Quality & Repurchase Intention & Product Variations \\
\hline KL1 & 0,819 & 0,855 & 0,789 & 0,839 \\
\hline KL2 & 0,853 & 0,940 & 0,955 & 0,962 \\
\hline KL3 & 0,702 & 0,888 & 0,870 & 0,803 \\
\hline KL4 & 0,855 & 0,882 & 0,918 & 0,842 \\
\hline KL5 & 0,718 & 0,899 & 0,870 & 0,808 \\
\hline KP1 & 0,740 & 0,512 & 0,485 & 0,544 \\
\hline KP2 & 0,832 & 0,684 & 0,700 & 0,648 \\
\hline KP3 & 0,769 & 0,563 & 0,570 & 0,569 \\
\hline KP4 & 0,702 & 0,888 & 0,870 & 0,803 \\
\hline KP5 & 0,675 & 0,484 & 0,475 & 0,495 \\
\hline RI2 & 0,702 & 0,888 & 0,870 & 0,803 \\
\hline RI1 & 0,853 & 0,940 & 0,955 & 0,962 \\
\hline RI3 & 0,855 & 0,882 & 0,918 & 0,842 \\
\hline VP1 & 0,830 & 0,919 & 0,934 & 0,953 \\
\hline VP2 & 0,801 & 0,852 & 0,820 & 0,917 \\
\hline VP3 & 0,579 & 0,732 & 0,714 & 0,778 \\
\hline VP4 & 0,853 & 0,940 & 0,955 & 0,962 \\
\hline
\end{tabular}

Source: data processed through SmartPLS, 2019

The table above shows the loading value of the KL2, KL4, KP4, RI2 and RI1 indicators on the corresponding variable which is smaller than the other variables, so discriminant validity does not meet. And also that the AVE value in each variable is not greater than the other variables so that the indicator is omitted from the PLS model which is shown in the following cross loading table:

Table 4.7. Cross loading after indicator elimination

\begin{tabular}{|c|c|c|c|c|}
\hline Indikator & Satisfaction & Service Quality & Repurchase Intention & Product Variations \\
\hline VP.1 & 0,710 & 0,834 & 0,848 & 0,959 \\
\hline VP.2 & 0,702 & 0,829 & 0,752 & 0,919 \\
\hline VP.3 & 0,347 & 0,763 & 0,533 & 0,857 \\
\hline VP.4 & 0,733 & 0,852 & 0,870 & 0,968 \\
\hline KL.1 & 0,750 & 0,863 & 0,734 & 0,845 \\
\hline KL.3 & 0,412 & 0,928 & 0,648 & 0,793 \\
\hline KL.5 & 0,439 & 0,945 & 0,655 & 0,799 \\
\hline KP.1 & $\mathbf{0 , 7 5 4}$ & 0,501 & 0,461 & 0,543 \\
\hline KP.2 & $\mathbf{0 , 8 6 0}$ & 0,580 & 0,810 & 0,656 \\
\hline KP.3 & $\mathbf{0 , 8 7 2}$ & 0,458 & 0,672 & 0,584 \\
\hline KP.5 & $\mathbf{0 , 7 9 2}$ & 0,429 & 0,509 & 0,505 \\
\hline RI.3 & 0,782 & 0,755 & 1,000 & 0,847 \\
\hline
\end{tabular}

Sumber: data processed through SmartPLS, 2019

The table above shows that the cross loading data above after several indicators are removed, then the cross loading value is fulfilled because it has the largest value compared to the cross loading value on other variables. 


\subsection{SEM-PLS Model}

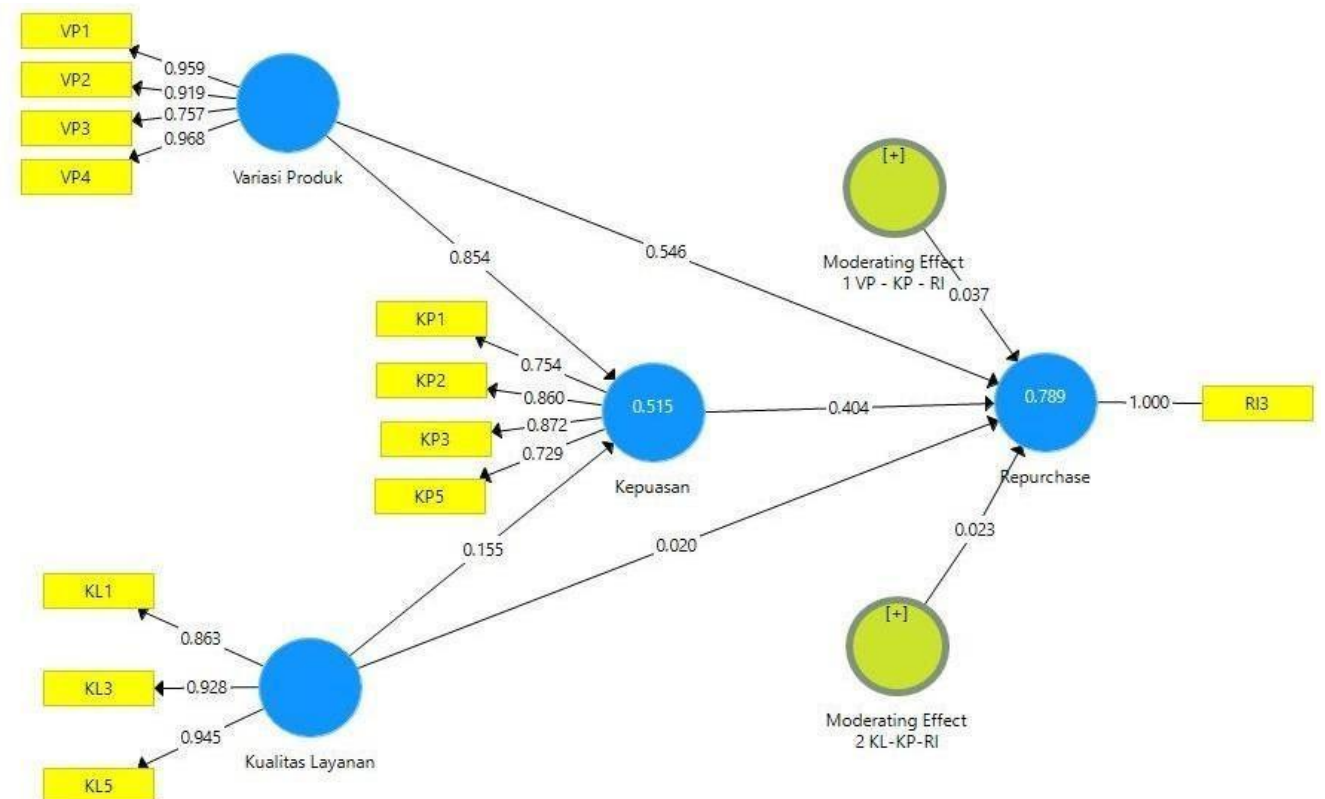

Figure 4.2. PLS models

\subsubsection{Evaluation of Measurement Model (Outer Model)}

1. Convergent Validity

Table 4.8. Outer Loading

\begin{tabular}{|l|c|c|c|}
\hline \multicolumn{1}{|c|}{ Variable } & Indicator & Outer loading & Conclusion \\
\hline \multirow{4}{*}{ Product Variation $\left(\mathrm{X}_{1}\right)$} & VP.1 & $\mathbf{0 , 9 5 9}$ & Valid \\
\cline { 2 - 4 } & VP.2 & $\mathbf{0 , 9 1 9}$ & Valid \\
\cline { 2 - 4 } & VP.3 & $\mathbf{0 , 8 5 7}$ & Valid \\
\cline { 2 - 4 } & VP.4 & $\mathbf{0 , 9 6 8}$ & Valid \\
\hline Quality of Service $\left(\mathrm{X}_{2}\right)$ & KL.1 & $\mathbf{0 , 8 6 3}$ & Valid \\
\cline { 2 - 4 } & KL.3 & $\mathbf{0 , 9 2 8}$ & Valid \\
\cline { 2 - 4 } & KL.5 & $\mathbf{0 , 9 4 5}$ & Valid \\
\hline \multirow{3}{*}{ Satisfaction $\left(\mathrm{Y}_{1}\right)$} & KP.1 & $\mathbf{0 , 7 5 4}$ & Valid \\
\cline { 2 - 4 } & KP.2 & $\mathbf{0 , 8 6 0}$ & Valid \\
\cline { 2 - 4 } & KP.3 & $\mathbf{0 , 8 7 2}$ & Valid \\
\cline { 2 - 4 } & KP.5 & $\mathbf{0 , 7 2 9}$ & Valid \\
\hline Repurchase Intention $\left(\mathrm{Y}_{2}\right)$ & RI.3 & $\mathbf{1 , 0 0 0}$ & Valid \\
\hline
\end{tabular}

Source: data processed through SmartPLS, 2019

The table above shows that each indicator on the variable has an outer loading value of more than 0.70 so that all indicators deserve to be said to be valid.

Another method is to look at the average variant extracted (AVE) value for each indicator on condition that the value must be $>0.5$ for a good model (Ghozali, 2014).

Table 4.9. Average Variant Extracted

\begin{tabular}{|c|c|}
\hline Variable & AVE \\
\hline Product Variations & 0,818 \\
\hline Service Quality & 0,832 \\
\hline Customer satisfaction & 0,650 \\
\hline Repurchase Intention & 1,000 \\
\hline
\end{tabular}

Source: data processed through SmartPLS, 2019

The table above shows that product variation, service quality, customer satisfaction and repurchase intention have an AVE value greater than 0.5. It can be interpreted that the indicator has a correlation with the latent variable. The greater the AVE value, the higher the ability to explain the value of the indicators that measure the latent variable. 
2. Discriminant Validity

Table 4.10. Cross loading

\begin{tabular}{|c|r|r|r|r|}
\hline Indicator & Satisfaction & Service Quality & Repurchase Intention & Product Variations \\
\hline VP.1 & 0,710 & 0,834 & 0,848 & 0,959 \\
\hline VP.2 & 0,702 & 0,829 & 0,752 & 0,919 \\
\hline VP.3 & 0,347 & 0,763 & 0,533 & 0,857 \\
\hline VP.4 & 0,733 & 0,852 & 0,870 & 0,968 \\
\hline KL.1 & 0,750 & 0,863 & 0,734 & 0,845 \\
\hline KL.3 & 0,412 & 0,928 & 0,648 & 0,793 \\
\hline KL.5 & 0,439 & 0,945 & 0,655 & 0,799 \\
\hline KP.1 & $\mathbf{0 , 7 5 4}$ & 0,501 & 0,461 & 0,543 \\
\hline KP.2 & $\mathbf{0 , 8 6 0}$ & 0,580 & 0,810 & 0,656 \\
\hline KP.3 & $\mathbf{0 , 8 7 2}$ & 0,458 & 0,672 & 0,584 \\
\hline KP.5 & $\mathbf{0 , 7 9 2}$ & 0,429 & 0,509 & 0,505 \\
\hline RI.3 & 0,782 & 0,755 & 1,000 & 0,847 \\
\hline
\end{tabular}

Source: data processed through SmartPLS, 2019

The discriminant validity model is good if the AVE on the variable itself is greater than the correlation between other variables.

Table 4.11. AVE and AVE tables

\begin{tabular}{|c|c|r|}
\hline Variable & AVE & \multicolumn{1}{|c|}{ AVE } \\
\hline Product Variations & 0,818 & 0,905 \\
\hline Service Quality & 0,832 & 0,912 \\
\hline Customer satisfaction & 0,650 & 0,806 \\
\hline Repurchase Intention & 1,000 & 1,000 \\
\hline
\end{tabular}

Source: data processed through SmartPLS, 2019

Table 4.12. Fornell-Larcker

\begin{tabular}{|c|c|c|c|c|c|c|}
\hline & $\begin{array}{l}\text { Customer } \\
\text { satisfaction }\end{array}$ & $\begin{array}{l}\text { Service } \\
\text { Quality }\end{array}$ & $\begin{array}{l}\text { Moderating Effect } 1 \\
\text { (product variation - } \\
\text { satisfaction - } \\
\text { repurchase) }\end{array}$ & $\begin{array}{c}\text { Moderating Effect } 2 \\
\text { (Quality of service - } \\
\text { Satisfaction - } \\
\text { Repurchase Itention) }\end{array}$ & $\begin{array}{l}\text { Repurchase } \\
\text { Intention }\end{array}$ & $\begin{array}{c}\text { Product } \\
\text { Variations }\end{array}$ \\
\hline Customer satisfaction & 0.806 & & & & & \\
\hline Service Quality & 0.614 & 0.912 & & & & \\
\hline $\begin{array}{l}\text { Moderating Effect } 1 \\
\text { (product variation - } \\
\text { satisfaction - } \\
\text { repurchase) }\end{array}$ & -0.291 & -0.041 & 1,000 & & & \\
\hline $\begin{array}{l}\text { Moderating Effect } 2 \\
\text { (Quality of service - } \\
\text { Satisfaction - } \\
\text { Repurchase Itention) }\end{array}$ & -0.224 & -0.054 & 0.954 & 1,000 & & \\
\hline Repurchase Intention & 0.782 & 0.755 & -0.064 & -0.025 & 1,000 & \\
\hline Product Variations & 0.714 & 0.900 & -0.066 & -0.042 & 0.847 & 0.905 \\
\hline
\end{tabular}

Source: data processed through SmartPLS, 2019

The table above can be seen that the AVE value of 0.806 on the customer satisfaction variable is greater than the other variables. It also applies to other variables, the AVE value on the variable itself shows a higher number than the correlation between variables. Thus, it can be interpreted that it has fulfilled the discriminant validity requirements indicated by the AVE value that has been fulfilled.

3. Composite Reliability and Cronbach Alpha

Table 4.13. Reliability

\begin{tabular}{|c|c|c|}
\hline Variable & Cronbach's Alpha & Composite Reliability \\
\hline Product Variations & 0.925 & 0.947 \\
\hline Service Quality & 0.901 & 0.937 \\
\hline Customer satisfaction & 0.821 & 0.881 \\
\hline Repurchase Intention & 1,000 & 1,000 \\
\hline
\end{tabular}


The table above shows that the Cronbach alpha value for each variable has met the requirements above, namely greater than 0.7 and the same as composite reliability, the value for each variable is greater than 0.7 . It can be concluded that all indicators can be declared reliable in measuring latent variables and overall variables have a high level of reliability.

\subsubsection{Evaluation of the structural model (inner model)}

1. Model Goodness Test (Goodness of Fit)

Table 4.14. R-Square

\begin{tabular}{|l|c|}
\hline & R Square \\
\hline Satisfaction & 0.515 \\
\hline Repurchase Intention_ & 0.789 \\
\hline
\end{tabular}

Supported by a picture of the PLS model structure in Figure 4.1, it can be summarized as a whole by referring to the R-Square value which is used to see how much the dependent variable (Y1 and Y2) is influenced by the independent variables, namely (X1 and X2) (Kusuma et al., 2018) through the following table:

Table 4.15. Q-Square

\begin{tabular}{|c|c|c|}
\hline Criteria & Value & Cut-Off Value \\
\hline $\begin{aligned} \text { Q-Square }=1-\left(1-\mathrm{R} 1^{2}\right)\left(1-\mathrm{R} 2^{2}\right) \\
\text { Q-Square }=1-(1-0,515)(1-0,789) \\
=1-(0,485)(0,211) \\
=0,897\end{aligned}$ & 0,897 & Between $0-1$, closer to 1 the better \\
\hline
\end{tabular}

Source: data processed through SmartPLS, 2019

Table 4.15. shows that the goodness of fit assessment can be known through the Q-square value, the QSquare value means the same as the coefficient determination (R-Square) in the regression analysis, where the higher the Q-Square, the model can be said to be better or more fit with data. The table above shows that the Q-Square (predictive-relevance) value has a value of 0.897 or $89.7 \%$. This value indicates that the variable repurchase intention and customer satisfaction can be explained by the variable product variation and overall service quality of $89.7 \%$. And the rest is influenced by other factors outside this research model of $10.3 \%$.

\subsubsection{Hypothesis testing}

1. Significance Test (Bootstraping)

Outer Loadings

Table 4.16. Outer loading bootstraping

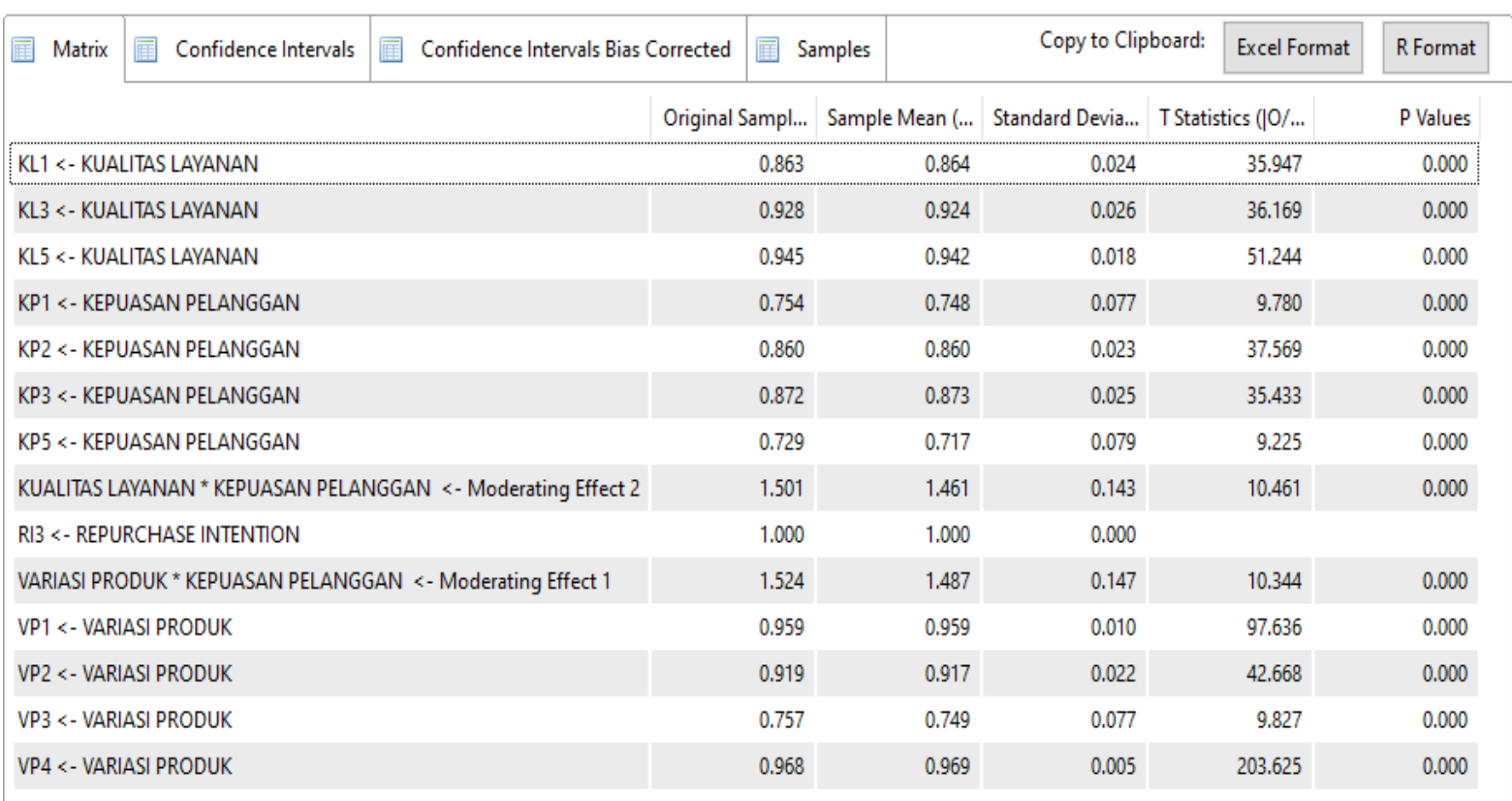

Table 4.16 outer loading above shows that the p-value is smaller than 0.05 . This means that the above indicators can measure or explain the appropriate variables. 


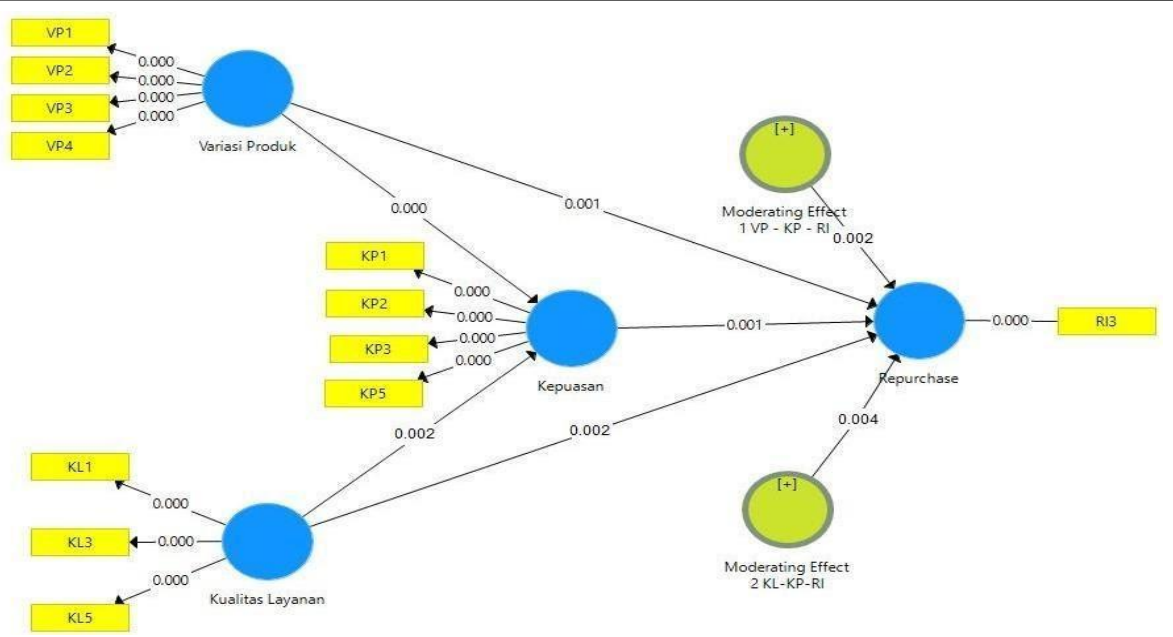

Figure 4.3. PLS Bootstrapping Model

With the aim of ensuring that a hypothesis can be said to be accepted or rejected, it can be done by taking into account the significance values between constructs, $t$-statistics and $p$-values. The bootstrapping method in this study, the hypothesis is accepted if the significance value of t-values is greater than 1.96 if the error rate is $5 \%$, and 1.65 with an error rate of $10 \%$. The p-value is less than 0.05 , then $\mathrm{Ha}$ is accepted and if it is greater than 0.05 then Ho is rejected.

Table 4.17. Results of t-statistics and p-value

\begin{tabular}{|l|r|r|r|r|r|}
\hline \multicolumn{1}{|c|}{ Hypothesis } & $\begin{array}{c}\text { Original } \\
\text { Sample (O) }\end{array}$ & $\begin{array}{c}\text { Sample } \\
\text { Mean (M) }\end{array}$ & $\begin{array}{c}\text { Standard } \\
\text { Deviation } \\
\text { (STDEV) }\end{array}$ & $\begin{array}{c}\text { T Statistics } \\
(\mid \mathbf{O} / \text { STDEV|) }\end{array}$ & P Values \\
\hline Product Variation -> Customer Satisfaction & 0.854 & 0.862 & 0.162 & 5,259 & 0.000 \\
\hline Service Quality -> Customer Satisfaction & 0.155 & 0.163 & 0.173 & 2,894 & 0.002 \\
\hline Customer Satisfaction -> Repurchase Intention & 0.404 & 0.391 & 0.122 & 3,314 & 0.001 \\
\hline $\begin{array}{l}\text { Moderating Effect 1 (product variation - } \\
\text { satisfaction - repurchase) -> Repurchase Intention }\end{array}$ & 0.037 & 0.379 & 0.127 & 3.185 & 0.002 \\
\hline $\begin{array}{l}\text { Moderating Effect 2 (Quality of service } \\
\text { - Satisfaction - Repurchase Intention) -> } \\
\text { Repurchase Intention }\end{array}$ & 0.023 & 0.026 & 0.173 & & 2,136 \\
\hline
\end{tabular}

\section{Source: data processed through SmartPLS, 2019}

The following is an explanation of the five hypotheses based on the table above:

a. H1: Product variations have a significant effect on TB Triguna customer satisfaction.

The hypothesis is accepted and stated that there is a significant effect of product variations on customer satisfaction. Because the p-value of 0.000 is smaller than 0.05 , then $\mathrm{H} 0$ is small.

b. H2: Service quality has a significant effect on customer satisfaction for TB Triguna.

The hypothesis is accepted because it meets the criteria, namely the p-value of 0.002 is smaller than 0.05 and the T-statistical value of 2.894 is more than 1.65. Service quality has a significant effect on customer satisfaction at TB Triguna.

c. H3 : Customer satisfaction has a significant effect on repurchase intention for TB Triguna.

The results of the third hypothesis are that the p-value is 0.05 smaller, the p-value is $0.001<0.05$ and the T-statistic value is 3.314 which is above the 1.65 value. From these criteria it can be interpreted that $\mathrm{Ha}$ is accepted and shows that there is a significant effect of the customer satisfaction variable on repurchase intention.

d. H4: Product variations have a significant effect on repurchase intention mediated by TB Triguna customer satisfaction.

This fourth hypothesis shows that the hypothesis is accepted, which means that product variations have a significant effect on repurchase intention mediated by customer satisfaction at TB Triguna. the p-value of 0.002 is smaller than 0.05 and the T-statistic value of 3.185 is above the criterion of 1.65 so that Ha is accepted. 
e. H5: Service quality has a significant effect on repurchase intention mediated by TB Triguna customer satisfaction.

With a p-value of 0.004 which is smaller than 0.05 , then Ha is accepted with a T-statistic value of 2.136 meeting the criteria above 1.65. Based on the calculation results, the fifth hypothesis is rejected and it can be stated that service quality has a significant effect on repurchase intention mediated by TB Triguna customer satisfaction.

\section{Conclusions and Practical Implication}

\subsection{Conclusion}

Product variations affect customer satisfaction. Based on the results of the PLS test, it shows that product variations have a significant effect on customer satisfaction. The more variety of products that TB Triguna provides by providing various product sizes, various product quality, product completeness and providing various brands of tools and building materials, the more customer needs will be fulfilled and will have an impact on increasing customer satisfaction when buying products at TB Triguna.

Service quality has an effect on customer satisfaction. The results of statistical data analysis show that service quality has a significant effect on customer satisfaction. Customers will feel satisfied with the service by fulfilling the three indicators, namely physical evidence (tangible), responsiveness (responsiveness), and empathy (empathy). If the service quality of TB Triguna matches or exceeds customer expectations, the customer will be satisfied.

Customer satisfaction has an effect on repurchase intention. Based on the results of the study, it showed that satisfaction had a significant effect on repurchase intention. The satisfaction felt by consumers will encourage repeat transactions in the future. Shown by making TB Triguna the main choice in buying building equipment.

Product variations have a significant effect on repurchase intention mediated by customer satisfaction. The more diverse and complete the products offered by the store, the higher the level of customer satisfaction, if the customer is satisfied, they will repurchase at the same place.

Service quality has a significant effect on repurchase intention mediated by customer satisfaction. The results of the study indicate that to increase customer repurchase intention, the company must improve the quality of service which in turn will trigger high customer satisfaction. Therefore, it is important for companies to provide quality services to consumers.

Service quality has a significant effect on repurchase intention mediated by customer satisfaction. The results of the study indicate that to increase customer repurchase intention, the company must improve the quality of service which in turn will trigger high customer satisfaction. Therefore, it is important for companies to provide quality services to consumers.

\subsection{Practical Implication}

Table 5.1. Managerial Implications

\begin{tabular}{|c|c|c|c|}
\hline Variable & Before research & Research result & After research \\
\hline $\begin{array}{l}\text { 1. Product } \\
\text { variations on } \\
\text { customer } \\
\text { satisfaction }\end{array}$ & $\begin{array}{l}\text { As big as } 18.6 \% \text { of } \\
\text { customers asked about TB } \\
\text { Triguna product variants } \\
\text { from iron thickness, metal } \\
\text { paint color and furniture } \\
\text { fittings. }\end{array}$ & $\begin{array}{l}\text { Some people will not buy tools } \\
\text { and building materials until they } \\
\text { know the wide selection of } \\
\text { products and their } \\
\text { quality. Product variety also has a } \\
\text { role for customers to choose, } \\
\text { especially to maintain people's } \\
\text { hearts. It is based on the mean } \\
\text { value of } 3.9022 \text { from the results } \\
\text { of the distribution of respondents } \\
\text { on the completeness of the } \\
\text { product. }\end{array}$ & $\begin{array}{l}\text { - Implement space management or } \\
\text { planogram and manage space shelf } \\
\text { - Considering customer input in } \\
\text { adding products that are not yet } \\
\text { available on TB Triguna. }\end{array}$ \\
\hline $\begin{array}{l}\text { 2. Quality of } \\
\text { Service on } \\
\text { customer } \\
\text { satisfaction }\end{array}$ & $\begin{array}{l}\text { - Employees do not have } \\
\text { sufficient knowledge a lot } \\
\text { on some items, for } \\
\text { example related to } \\
\text { furniture. }\end{array}$ & $\begin{array}{l}\text { - Triguna employees don't look } \\
\text { neat and the location of TB } \\
\text { triguna is on a rural road instead } \\
\text { of a highway, so new } \\
\text { customers who want to go to TB } \\
\text { triguna location need }\end{array}$ & $\begin{array}{l}\text { - Provide information and training to } \\
\text { employees regarding merchandise. } \\
\text { - Enrich product knowledge with sales } \\
\text { and customers on a product. In order } \\
\text { to accurately provide explanations to } \\
\text { customers and be able to understand }\end{array}$ \\
\hline
\end{tabular}




\begin{tabular}{|c|c|c|c|}
\hline & $\begin{array}{l}\text { Employees have not been } \\
\text { able to provide detailed } \\
\text { product information. } \\
\text { Employees have not been } \\
\text { able to respond to } \\
\text { complaints quickly. }\end{array}$ & $\begin{array}{l}\text { directions. This is based on the } \\
\text { mean value of respondents' } \\
\text { distribution of } 2.9565 \text { on tangible } \\
\text { indicators. }\end{array}$ & $\begin{array}{l}\text { the needs of TB Triguna customers } \\
\text { appropriately so as to increase } \\
\text { customer satisfaction. } \\
\text { - Providing services that exceed } \\
\text { standards by improving internal } \\
\text { communication to best serve } \\
\text { customers. } \\
\text { - Perform service recovery by } \\
\text { applying attributes in service } \\
\text { improvement }\end{array}$ \\
\hline $\begin{array}{l}\text { 3. Customer } \\
\text { satisfaction with } \\
\text { repurchase intention }\end{array}$ & $\begin{array}{l}\text { Some customers feel } \\
\text { unsatisfied, because there } \\
\text { are several products they are } \\
\text { looking for at TB Triguna } \\
\text { but they are not yet } \\
\text { available, and employees } \\
\text { have not been able to clearly } \\
\text { describe the products } \\
\text { available at TB Triguna. }\end{array}$ & $\begin{array}{l}\text { - Satisfaction with customers affects } \\
\text { repurchase intention } \\
\text { - Most of the respondents agree with } \\
\text { the statement on the indicator that } \\
\text { they are satisfied with the product } \\
\text { that has been purchased with a } \\
\text { value of } 4.2609\end{array}$ & $\begin{array}{l}\text { - Conduct post-purchase evaluations } \\
\text { (contact customers, assist with } \\
\text { product installation and establish } \\
\text { realistic expectations) }\end{array}$ \\
\hline $\begin{array}{l}\text { 4. Product } \\
\text { variations affect } \\
\text { Repurchase } \\
\text { Intention mediated } \\
\text { by customer } \\
\text { satisfaction }\end{array}$ & $\begin{array}{l}\text { Parties TB Triguna has } \\
\text { not provided a description } \\
\text { of the variety of products } \\
\text { includes many products, } \\
\text { product size, color products, } \\
\text { and product design to the } \\
\text { customer so that the } \\
\text { customer is not satisfied in } \\
\text { selecting and determining } \\
\text { the choice of the expected } \\
\text { product. }\end{array}$ & $\begin{array}{l}\text { TB Triguna only relies on product } \\
\text { descriptions obtained from sales and } \\
\text { promotion of new items from sales in } \\
\text { a limited number, so that some } \\
\text { customers do not know the product } \\
\text { descriptions contained in TB } \\
\text { Triguna, this is based on the mean } \\
\text { value of product completeness of } \\
3.9022 \text { from the data on the } \\
\text { distribution of respondents. }\end{array}$ & $\begin{array}{l}\text { - Make a description of several } \\
\text { products in the form of booklets that } \\
\text { were not previously owned by TB } \\
\text { Triguna so that customers can be } \\
\text { satisfied in making choices. } \\
\text { - TB Triguna can improve service } \\
\text { quality by enriching product-related } \\
\text { information through sales on } \\
\text { products at TB Triguna. }\end{array}$ \\
\hline $\begin{array}{l}\text { 5. Service quality } \\
\text { has an effect on } \\
\text { mediated } \\
\text { repurchase intention } \\
\text { customer } \\
\text { satisfaction }\end{array}$ & $\begin{array}{l}\text { There is no guarantee or } \\
\text { agreement between TB } \\
\text { Triguna and the customer } \\
\text { within the time agreed by } \\
\text { both parties for the product } \\
\text { purchased by the customer. }\end{array}$ & $\begin{array}{l}\text { Customers have not been able to } \\
\text { complain about the purchased } \\
\text { product, this is because TB Triguna } \\
\text { has not provided a guarantee (or } \\
\text { agreement on the product purchased } \\
\text { if there is a defect after purchase, this } \\
\text { is based on the mean indicator value } \\
\text { data. from the distribution of } \\
\text { respondent data. }\end{array}$ & $\begin{array}{l}\text { - Paying attention to input and } \\
\text { suggestions from customers in order } \\
\text { to be able to increase customer } \\
\text { satisfaction by providing guarantees } \\
\text { for products with a certain nominal } \\
\text { and tempo, TB Triguna employees } \\
\text { appropriately provide customer } \\
\text { needs with the hope that if the } \\
\text { customer is satisfied, they will } \\
\text { repurchase at the same place. }\end{array}$ \\
\hline
\end{tabular}

Source: data processed, 2019

\section{References}

Aji, A. S., \& Marleni, N. N. N. (2018). Survei kepuasan pelanggan PDAM Kota Balikpapan. Unimma Press.

Arsyanti, N. M., \& Astuti, S. R. T. (2016). Analisis pengaruh kualitas produk, kualitas layanan dan keragaman produk terhadap kepuasan pelanggan serta dampaknya terhadap minat beli ulang (Studi pada Toko Online Shopastelle, Semarang). Diponegoro Journal of Management, 5(2), 291-301.

Duarte, A. F., Moreira, V. R., Ferraresi, A. A., \& Gerhard, A. (2016). Evaluating credit union members' perception of service quality through service innovation. RAI Revista de Administração e Inovação, 13(4), 242-250. https://doi.org/10.1016/j.rai.2016.06.007

Ebrahim, R., Ghoneim, A., Irani, Z., \& Fan, Y. (2016). A brand preference and repurchase intention model: The role of consumer experience. Journal of Marketing Management, 32(13-14), 1230-1259. https://doi.org/10.1080/0267257X.2016.1150322

Fang, J., Wen, C., George, B., \& Prybutok, V. R. (2016). Consumer heterogeneity, perceived value, and repurchase decision-making in online shopping: The role of gender, age, and shopping motives. Journal of Electronic Commerce Research, 17(2), 116-131@ article $\{$ faradisa2016analisis, title= $\{$ Anali.

Faradisa, I., Hasiholan, L. B., \& Minarsih, M. M. (2016). Analisis pengaruh variasi produk, fasilitas, dan kualitas pelayanan terhadap minat beli ulang konsumen pada Indonesian coffeeshop Semarang (ICOS CAFE). Journal of Management, 2(2), 1-13. 
Ghozali, I. (2014). Structural equation modeling metode alternatif dengan Partial Least Square (PLS) dilengkapi software SmartPLS 3.00 Xistat 2014 dan WarpPLS 4.0 (4th ed.). Semarang: Badan Penerbit Universitas Diponegoro Semarang.

Ghozali, I., \& Latan, H. (2015). Partial least squares konsep, teknik dan aplikasi menggunakan program smartpls 3.0 untuk penelitian empiris. Semarang: Badan Penerbit UNDIP.

Hellier, P. K., Geursen, G. M., Carr, R. A., \& Rickard, J. A. (2003). Customer repurchase intention. European Journal of Marketing, 37(11/12), 1762-1800. https://doi.org/10.1108/03090560310495456

Hill, N., \& Alexander, J. (2017). The handbook of customer satisfaction and loyalty measurement. New York: Routledge.

Kotler, P. (2008). Manajemen Pemasaran. Jilid 2 (12nd ed.). Jakarta: PT Indeks.

Kotler, P., \& Amstrong, G. (2013). Prinsip-prinsip pemasaran (7th ed.). Jakarta: Erlangga.

Kotler, P., \& Keller, K. L. (2016). Marketing management (15th ed.). New Jersey : Pearson Education South Asia PTe Ltd.

Kusuma, K., Utami, C. W., \& Padmalia, M. (2018). Pemediasian kepuasan konsumen pada pengaruh kualitas layanan dan harga terhadap minat beli ulang perusahaan Sinar Karya Pemenang. 3(3), 363-371.

Malhotra, N. K. (2010). Marketing research: An applied orientation (6th ed.). ew Jersey: Pearson Education.

Ngoc Duy Phuong, N., \& Thi Dai g, T. (2018). Repurchase intention: The effect of service quality, system quality, information quality, and customer satisfaction as mediating role: A PLS approach of m-commerce ride hailing service in Vietnam. Marketing and Branding Research, 5(2), 78-91. https://doi.org/10.33844/mbr.2018.60463

Nugroho, B. I., Hadiwidjojo, D., Rahman, F., \& Rahayu, M. (2017). Service quality perception's effect on customer satisfaction and repurchase intention. European Business \& Management, 3(3), 37-46. https://doi.org/10.11648/j.ebm.20170303.11

Septiawati, R. (2018). Pengaruh kualitas pelayanan terhadap niat pembelian ulang produk dengan kepuasan pelanggan sebaga variabel mediasi. Universitas Lampung.

Shahid Iqbal, M., U1 Hassan, M., \& Habibah, U. (2018). Impact of self-service technology (SST) service quality on customer loyalty and behavioral intention: The mediating role of customer satisfaction. Cogent Business \& Management, 5(1), 1-23. https://doi.org/10.1080/23311975.2018.1423770

Sugiyono. (2017). Metode penelitian kuantitatif, kualitatif, dan R\&D. Bandung: Alfabeta.

Utami, C. W. (2006). Manajemen ritel: Strategi dan implementasi modern. Edisi Pertama. Jakarta: Salemba Empat.

Wikhamn, W. (2019). Innovation, sustainable HRM and customer satisfaction. International Journal of Hospitality Management, 76, 102-110. https://doi.org/10.1016/j.ijhm.2018.04.009 